\title{
Advancing the entrepreneurial orientation construct: the role of passion and perseverance
}

Article

Accepted Version

Gerschewski, S., Lindsay, V. J. and Rose, E. L. (2016) Advancing the entrepreneurial orientation construct: the role of passion and perseverance. Review of International Business and Strategy, 26 (4). pp. 446-471. ISSN 2059-6014 doi: https://doi.org/10.1108/RIBS-08-2016-0042 Available at https://centaur.reading.ac.uk/74993/

It is advisable to refer to the publisher's version if you intend to cite from the work. See Guidance on citing.

To link to this article DOI: http://dx.doi.org/10.1108/RIBS-08-2016-0042

Publisher: Emerald Publishing Limited

All outputs in CentAUR are protected by Intellectual Property Rights law, including copyright law. Copyright and IPR is retained by the creators or other copyright holders. Terms and conditions for use of this material are defined in the End User Agreement.

www.reading.ac.uk/centaur 
Central Archive at the University of Reading

Reading's research outputs online 


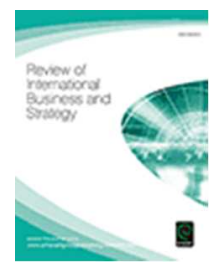

\section{Advancing the entrepreneurial orientation construct: The role of passion and perseverance}

\begin{tabular}{|r|l|}
\hline Journal: & Review of International Business and Strategy \\
\hline Manuscript ID & Draft \\
\hline Manuscript Type: & Empirical Research Paper \\
\hline Keywords: & $\begin{array}{l}\text { Entrepreneurial orientation, Born global firm, Passion, Perseverance, } \\
\text { International entrepreneurship }\end{array}$ \\
\hline \multicolumn{2}{|c}{} \\
\hline
\end{tabular}

SCHOLARONE $^{m}$

Manuscripts 


\title{
Advancing the entrepreneurial orientation construct:
}

\section{The role of passion and perseverance}

\begin{abstract}
The purpose of this study is to examine how entrepreneurial orientation (EO) is manifested in the context of born global firms. Specifically, we investigate the extent to which the EO dimensions of the influential Miller/Covin \& Slevin scale are demonstrated in born globals. In addition, following calls in the literature, we examine some as-yet unrecognised dimensions of EO in born globals. Based on semi-structured, in-depth, qualitative interviews with eight born global firms from New Zealand and Australia, we find that the EO dimensions of proactiveness and innovativeness are strongly prevalent in these firms. In contrast to the extant literature, our results also indicate that these born global firms generally display a relatively low level of risk-taking. We find strong empirical support for two additional emerging dimensions of EO: passion and perseverance. Our study provides two key contributions to the area of international entrepreneurship: (1) by investigating how EO is prevalent in the context of born globals, and (2) by proposing the new dimensions of passion and perseverance.
\end{abstract}

\section{Keywords}

Entrepreneurial orientation

Born global firm

Passion

Perseverance

International entrepreneurship

\section{Introduction}

International entrepreneurship (IE), which integrates the disciplines of international business and entrepreneurship, has received increased interest from scholars over the past two decades (Fletcher, 2004; Jones et al., 2011; Keupp and Gassmann, 2009; Knight, 2001; McDougall and Oviatt, 2000). Commonly defined as "the discovery, enactment, evaluation, and 
exploitation of opportunities - across national borders - to create future goods and services" (Oviatt and McDougall, 2005, p. 7), several areas of international entrepreneurship have been explored in the literature, such as internationalisation patterns of born globals, networks and social capital, and knowledge and capabilities of born globals (see Jones et al., 2011 for an extensive review of the IE literature). Three major research strands of IE have been identified: (1) entrepreneurial internationalisation, (2) international comparisons of entrepreneurship, and (3) comparative entrepreneurial internationalisation (Jones et al., 2011).

The "beginnings" of international entrepreneurship can be traced back to the late 1980s, when McDougall (1989) conducted a study comparing domestic and international new ventures. In the early 1990s, in a study of Australian manufacturing exporters, Rennie (1993, p. 9) originally coined the term "born global", stating that

...these firms view the world as their marketplace from the outset; they do not see foreign markets as useful adjuncts to the domestic market - quite the opposite, they see the domestic market as supporting their exporting business.

The following year, Oviatt and McDougall (1994) introduced a conceptual model to explain the emergence of international new ventures. While there have been various terms for early and rapidly internationalizing firms, such as "born globals" (Rennie, 1993), "high-technology start-ups" (Jolly et al., 1992) and "international new ventures" (Oviatt and McDougall, 1994), we adopt the term "born global" in this study as it is widely used by scholars (Cavusgil and Knight, 2009). Coviello et al. (2011) note that the terms born global and international new ventures have been used interchangeably in the scholarly literature.

From its emergence, IE scholars have recognised the relevance of entrepreneurial orientation (EO) to theory and practice within their domain (Covin and Miller, 2014). As noted by Covin and Miller (2014), the centrality of the EO construct to IE is widely acknowledged (see, for example, Joardar and $\mathrm{Wu}, 2011$; Jones and Coviello, 2005; 
Weerawardena et al., 2007).

IE studies have identified positive relationships between EO and the speed of international entry (Zhou 2007), international sales intensity (Zhang et al., 2012), international scope (Ripollés-Méliá et al., 2007), and financial measures of international performance (Zhang et al., 2009). ${ }^{1}$ The conversation on EO within the IE literature has been both extensive and varied (Covin and Miller, 2014), and has extended well beyond performance effects. In their review and commentary on EO within the domain of IE, Covin and Miller (2014) extend a call for researchers to investigate how EO can be used to better understand international ventures. They note that the vast majority of studies pertaining to EO have been quantitative, and that fine-grained qualitative studies are needed. Wales $(2016, \mathrm{p}$. 13) reiterate the strong need for qualitative studies, noting that "qualitative research will provide greater insight into how EO is manifested within organizations, yielding closer congruence between theorizing and managerial practice".

The purpose of our study is to examine how entrepreneurial orientation is demonstrated in the context of born global firms. In addition, in responding to the suggestion by Covin and Miller (2014), we explore the possibility of there being different, or additional, dimensions of the traditional EO construct for these firms. We see these as important contributions to theory refinement and development relating to the EO construct. Therefore, the key research question for this study is: "How is entrepreneurial orientation manifested in born global firms?"

In light of the exploratory nature of this research topic, and in answer to the call from Covin and Miller (2014), we employ a qualitative methodology, conducting in-depth interviews with senior managers from eight Australian and New Zealand born global firms.

\footnotetext{
${ }^{1}$ Other IE studies on the relationship between EO and various dimensions associated with internationalisation did not find significant relationships (e.g., Jantunen et al., 2005; Kuivalainen et al., 2004).
} 
Jones et al. (2011, p. 643) advocated that "we need a greater understanding of entrepreneurs and their teams as they related to entrepreneurial internationalization". In-depth interviews enabled us to probe the motivations and behaviours of the entrepreneurs and top management team members leading the born global companies in our study.

The paper is structured as follows. We provide a literature review on EO in the next section, followed by discussion of the research methodology. The interview findings are presented in our results section, which is followed by our discussion, limitations of the study, and conclusion.

\section{Literature review}

\section{Entrepreneurial orientation}

Entrepreneurial orientation is a concept that has been at the forefront of scholarly discourse in entrepreneurship over the past three decades. According to Slevin and Terjesen (2011, p. 978), EO is "central to entrepreneurship and strategy research", and has received more than 1,000 references in the extant literature. In one of the seminal studies on EO, Miller (1983, p. 771) argued that a firm is entrepreneurial when it "engages in product-market innovation, undertakes somewhat risky ventures, and is first to come up with 'proactive' innovations, beating competitors to the punch". Thus, according to Miller (1983), entrepreneurial orientation consists of the simultaneous occurrence of three dimensions: innovativeness, risktaking and proactiveness. Covin and Wales (2012) noted that these three dimensions should covary positively in order for EO to be present. Building on the work of Miller (1983), Covin and Slevin (1989, p. 79) defined an entrepreneurial strategic posture as characterised by "frequent and extensive technological and product innovation, an aggressive competitive orientation, and a strong risk-taking propensity by top management”. Both Miller (1983) and 
Covin and Slevin (1989) view entrepreneurial orientation as a unidimensional construct comprising the elements of proactiveness, risk-taking and innovativeness. This has become what is widely known in the literature as the Miller/Covin and Slevin (1989) scale (Covin and Wales, 2012; Slevin and Terjesen, 2011).

Defining EO as the "processes, practices, and decision-making activities that lead to new entry", Lumpkin and Dess (1996, p. 178) developed five dimensions of EO: proactiveness, risk-taking, innovativeness, competitive aggressiveness, and autonomy. In contrast to Covin and Slevin (1989), Lumpkin and Dess (1996) argued that these dimensions do not necessarily covary; instead, the authors considered EO as a multidimensional phenomenon. Thus, not all five factors need to be necessarily operating for a firm to be successful in "new entry" as a manifestation of entrepreneurship. Covin and Lumpkin (2011) suggest that the composite and multidimensional views of EO are not competing perspectives, but instead represent distinct constructs. Taken together, the Miller/Covin and Slevin (1989) and the Lumpkin and Dess (1996) scales have been widely-used perspectives in EO research (Covin and Lumpkin, 2011).

However, despite its extensive use, controversies remain regarding how to measure the EO construct appropriately (Covin and Lumpkin, 2011; Covin and Wales, 2012). Since Lyon, Lumpkin, and Dess (2000) raised the issue of advancing the EO construct, "little progress has been made in the development of new approaches to EO's assessment" (Covin and Wales, 2012, p. 678). In a similar vein, Rauch, Wiklund, Lumpkin, and Frese (2009) argued that the entrepreneurship construct would benefit from including additional variables. The inconsistent operationalisation of EO has been a particular issue in the context of born globals, often including a measure of international entrepreneurial orientation (IEO), to account for these firms' international environment and context. According to Covin and 
Miller (2014), IEO research can be differentiated into two main strands. The first approach, in essence, adopts traditional EO research with an internationalization-related dependent variable, such as export performance (e.g., Mostafa et al., 2006; Jantunen et al., 2008; Frishammar and Andersson, 2009), where IEO is not treated as a distinct construct from EO. The second IEO approach adjusts the traditional EO scales to account for the international operations of born globals, by including items such as "export markets" and "international business" (e.g., Knight and Cavusgil, 2004; Ibeh and Young, 2001), thus conceptualizing IEO as a subcategory of EO. Table 1 provides a review of the operationalizations of EO and IEO in the born global literature.

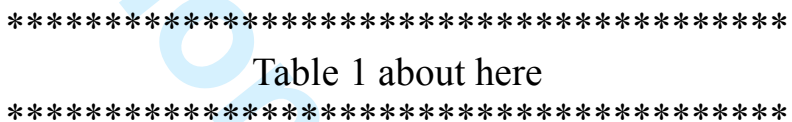

As shown in Table 1, there is heterogeneity in the operationalization of EO in the context of born globals. Knight (2001, p. 159) defined international entrepreneurial orientation as "a fundamental corporate posture, contributing strongly to the international performance of the SME. It emphasizes innovation, risk taking, and a generally proactive approach to business in foreign markets". Many studies (e.g., Knight and Cavusgil, 2004; Kropp et al., 2008; Zhou, 2007) have based their operationalisations on the seminal Miller/Covin and Slevin (1989) scale, and adapted them to the international context of born globals. In some cases, the original scales, as developed by Covin and Slevin (1989), have been used (e.g., Mostafa et al., 2006; Ripollés-Méliá et al., 2007; Frishammar and Andersson, 2009; Dai et al., 2014). Sundqvist et al., (2012) based their operationalisation of IEO on the five dimensions established by Lumpkin and Dess (1996). Our review suggests that born global studies have most generally focused on the three dimensions of proactiveness, innovativeness, and risk-taking.

Entrepreneurial orientation relates to a firm's strategic posture and specific traits 
associated with decision-making styles, practices, and methods (Lumpkin and Dess 1996; Covin and Slevin 1989). Schumpeter (1934) defined the entrepreneurship function as the introduction of new products and new production methods, the opening of new markets, the conquest of new sources of supply and raw materials, and the reorganization of an industry. With regard to entrepreneurial characteristics, Stewart et al. (1999) identified three key traits - achievement motivation, risk propensity, and preference for innovation - and found that entrepreneurs tended to display higher levels of these three characteristics, compared to corporate managers in larger firms. Kocak and Abimbola (2009) noted that entrepreneurial orientation is a key organisational capability of born global firms, which assists in identifying and exploiting opportunities, and expanding into overseas markets. Similarly, Karra et al., (2008) identified three entrepreneurial capabilities that were important for successful international new venture creation: international opportunity identification, institutional bridging, and a capacity and preference for cross-cultural collaboration.

Andersson (2000) defined three different types of entrepreneurs, each representing a different aspect of EO: technical, marketing, and structural. The technical entrepreneur is mainly interested in the development of new products and technology rather than internationalization per se. Internationalisation may thus occur through an enquiry from the firm's international network, which often leads to exporting or licensing agreements (Van Geenhuizen, 2008). As such, the approach to international markets for the technical entrepreneur is typically reactive and can be characterised as an international pull-strategy. On the other hand, the marketing entrepreneur has identified a need in the market and is proactive in developing new international opportunities. In reaching new customers, the marketing entrepreneur tends to commit large resources to penetrate markets quickly, which is manifested in the more frequent use of foreign direct investment (FDI). The choice of 
markets may be more dependent on personal preferences and networks, rather than "rational" calculation. Thus, the marketing entrepreneur typically uses an international push strategy. Finally, the structural entrepreneur is interested in restructuring companies and industries, and tends to operate in mature industries, aiming to combine organisations through mergers and acquisitions. Internationalisation is the consequence of the overall firm strategy, rather than a strategic goal for this type of entrepreneur (Andersson, 2000; Andersson et al., 2013).

In summary, while there is a large and growing literature on EO, our review revealed inconsistent operationalisations of EO/IEO in the context of born global firms. Most studies have used Covin and Slevin's (1989) scale as a foundation for measuring EO/IEO. However, despite calls in the literature, new approaches to measuring EO have been slow to emerge (Covin and Wales, 2012).

\section{Methodology}

We use a qualitative, interview-based, case approach to explore (i) how the EO construct is operationalised in born global firms, and (ii) the possibility of additional, as yet unidentified, dimensions of EO.

\section{Selection of Participant Firms}

In qualitative research, the process of identifying participants is generally driven by theoretical considerations rather than statistical representativeness (Miles and Huberman, 1994; Eisenhardt, 1989). Qualitative studies tend to use a purposive approach, as random sampling may reduce the logic and coherence that are characteristic of social processes to "uninterpretable sawdust" (Miles and Huberman, 1994, p. 27). Consistent with this line of thought, the study adopts a purposive sampling approach.

The main criteria for interview selection included being a New Zealand or Australian 
independently-owned company, and having exporting activities. All selected companies could be classified as born globals, according to the widely used definition of starting to internationalise within three years after establishment and achieving at least a $25 \%$ international sales ratio within this period (e.g., Knight and Cavusgil, 2004; Mort and Weerawardena, 2006; Gerschewski et al., 2015). In addition, consistent with the descriptive criteria expressed by Rennie (1993), the ventures in our sample viewed the world as their market place. Firms were selected that differed with respect to industry sector, company size, and foreign market selection, to provide variation for the analysis. The firms' details and characteristics were obtained through internet research (e.g., company and government export agency websites, newspaper articles) and information from the Dun \& Bradstreet database. In total, eight interviews were conducted (five New Zealand and three Australian companies), which provided apparent saturation of answers as the interviews progressed (Glaser and Strauss, 1967). Each company represented a 'case' for analytical purposes (Eisenhardt, 1989). The participating companies belonged to a variety of industry sectors, including manufacturing, information and communications technology (ICT), food, wine and education, and had an average of 38 employees. A detailed profile of the participating companies is shown in Table 2.

Table 2 about here

$* * * * * * * * * * * * * * * * * * * * * * * * * * * * * * * * * * * * * * * *$

We supplemented the interview recordings with archival firm data and case studies of the sampled companies. Thus, we employed triangulation of data resulting in cross-case comparisons which helped to uncover causal mechanisms in the context of EO for BGs. 


\section{Data Collection}

The data were collected via in-depth interviews with the firms' CEOs/owners or export/sales managers, as these informants were likely to be able to provide the most extensive and accurate information about their companies' international activities. The interviews centred on the topics of the firms' internationalisation and their entrepreneurial orientation. Semistructured interviews were utilised, to enable clearer comparison across the cases, and to ensure that the qualitative data were consistent enough to categorize and analyse (Morse, 2005). In addition, semi-structured interviews allowed the exploration of key topics based on an interview guide, and simultaneously offered discretion to follow new leads during the interviews (Bernard, 2006). Information collected through interviewing was supplemented with archival company data.

The interviews were conducted via telephone/Skype or face-to-face at the companies' premises. Each interview lasted for approximately one hour and was tape-recorded for later transcribing. Once transcribed, the interview summaries were shared with the respondents for clarification, and any changes were incorporated in the subsequent data analysis.

\section{Data Analysis}

Qualitative data analysis generally involves three concurrent flows of activity: data reduction, data display, and conclusion drawing/verification (Miles and Huberman, 1994). These three activities are interactive and interrelated and, therefore, form a continuous and iterative process (Miles and Huberman, 1994).

The audio-recorded interviews were transcribed before being imported into the NVivo software (Version 8) for data analysis. The use of computer-assisted qualitative data analysis (CAQDAS) has been recommended in the literature, due to its benefits, in terms of providing rigor and validity that may be difficult to achieve with manual methods (Lindsay, 2004). 
Following the recommendations by Miles and Huberman (1994), the interview transcripts were reviewed, and evolving patterns and themes identified. The qualitative research design involved pre-conceptualisation of issues developed from the literature review (Miles and Huberman, 1994), a process termed “a-priori categorization" by Sinkovics, Penz, and Ghauri (2008, p. 704). Following Sinkovics et al. (2008), the coding process also included additional "a posteriori" categorisation, with open coding allowing for the emergence of new themes. In sum, descriptive and subsequent pattern coding were applied in the course of the data analysis (Miles and Huberman, 1994), allowing for the development of rich insights into the "how" and "why" of entrepreneurial orientation in the context of born global firms.

\section{Results}

Figure 1 summarises the first two coding levels - (i.e., entrepreneurial orientation (level 1) and proactiveness (level 2) - of the coding structure arising from the analysis of the interview data. Following Miles and Huberman (1994), literature-based preconceptualisation led to the inclusion of some initial codes, notably those associated with the Covin and Slevin definition of EO. The interview findings were thus coded into the following key themes, in terms of the entrepreneurial orientation for the born global firms: global mindset, innovativeness, proactiveness, risk-taking, passion, and perseverance.

Figure 1 about here

All eight of the firms in our study demonstrated strong international orientation. A recurring theme was the global mindset of the entrepreneurs and top management team members who were interviewed. As expressed by our interviewees, their firms perceive the world, rather than their home country, as their marketplace, and see the potentially huge 
opportunities that global markets could offer to their business (Rennie, 1993; Fatehi and Ghadar, 2014). For example:

I'd say I don't even think of us as an exporter. I think of us as a global company. I mean you don't think of Coca-Cola as an exporter or HP as being an exporter. And I think, my personal view is, it limits the company's thinking if they think of themselves as an exporter. We are an international company and so, you know, I don't think New Zealand companies to grow should think of themselves as exporters unless the mentality is to sit behind the desk here and put stuff on ships and export it. We have to be in our markets and the difference to my mind is that's an international company not somebody who sits here and puts stuff on boats. So I don't like the term exporter. So we had, as I said, we had the mindset always that it was an international strategy and so it was just getting on planes and addressing those international markets and being seen as a global player. (ICT1)

Another interviewee noted that:

I suppose my mindset was if I can sell this in Australia, I can sell it anywhere in the world. (MFG1)

The excerpt from ICT1 is particularly interesting, as it suggests that thinking of oneself as an "exporter" that "sits behind the desk and puts stuff on boats and exports it" can be a detrimental mindset to the international development of a company. Rather, this seems to advocate a broader outlook, in terms of thinking as a global company that is actively present in its overseas markets, which may also entail internationalisation activities such as licensing and FDI. Five of the eight case companies were not "pure" exporters, but had used additional foreign servicing modes to enter their first international markets (e.g., licensing, sales and manufacturing subsidiaries, and strategic alliances). This mindset of being a "global company" has important implications for the firm's positioning in the international marketplace and the benefits associated with being perceived as a "global company" rather than an "exporter". As the manager from ICT1 commented:

It was really born as an international company. You know, I guess we started... the first products were sold in New Zealand, but the strategy right from the start was to 
take it global. (ICT1)

The global mindset adopted by ICT1 emphasizes the company's international orientation and gives literal support to the term born global.

Our interview questions also sought to probe the firms' levels of risk-taking, innovativeness, and proactiveness. Innovativeness and proactiveness were more in evidence than risk-taking in the born globals we studied.

Innovativeness emerged strongly from the interviews, especially in the forms of technical improvements and innovative business processes, as the following interview excerpts from respondents at OIL and FOOD illustrate:

We've been very innovative in the way that we designed the tool to make it a lot easier for the customer. We actually won an innovation award in 2004 for the product. We're trying on a daily basis to be innovative in the way we approach different markets and different business strategies and presenting opportunities to customers that they may not normally see. Sometimes they work, sometimes they don't. That's the learning curve we go through on a daily basis. (OIL)

We've just changed the shape of our container. We had to build a new container to be able to do it, because no one else is doing it. And we launched it about two months ago. And people have said to me: "Wow, that's a big, bold move to move away from the traditional round to rectangle". And we had our reasons for doing it. We think we shouldn't be doing the same thing. (FOOD)

The interviewee from MFG2 added that innovativeness is a key component for doing business in the global marketplace, arguing that the firm's products are not competing against low-cost producers, but are differentiated by their degree of innovativeness. Similarly, the representative from ICT1 noted that an innovative orientation is increasingly important, in order for the company to "stay ahead" and not to "get run over" by competitors. However, costs of innovativeness were highlighted by the manager from FOOD, who mentioned the difficulty of educating consumers about the company's new products: 
Sometimes it's easy to do, be same-same. Where with innovativeness comes a cost and the whole education process. So it's all fine and well for the government to sit there in their offices and say the only way that New Zealand is going to get out of the bottom of the OECD is to become innovative. Great, but at the end of the day there's a lot of education and there's a lot of money that needs to go in behind that. (FOOD)

The concept of proactiveness also evolved from the interviews. For example:

I'd like to go back to what I first said initially. I'm just following, it's just coming natural. I see an opportunity and I jump on it and I execute it and I make sure it happens. I don't sit here and think about what could have been? I don't ever want to die wondering, I suppose. (MFG1)

Similarly, the representative from FOOD noted:

Being responsive to enquiries, being proactive, keeping in contact with your people. We don't ever put our product on a boat and wave good-bye to it. We're very much there. And I think that if that's your idea of exporting, then you will be sadly mistaken. And I think it's being there. You know, like it's being there constantly. You can't do it from sitting here in New Zealand. You have to be there. (FOOD)

This suggests a proactive and aggressive approach towards the identification of new international market opportunities and underlines the drive of the entrepreneurs to "make things happen". As the comments suggest, "being there" in the markets and meeting and engaging with customers were considered as key ingredients for performing successfully on an international stage. As mentioned earlier, this may also be an important part of positioning the firm as a "global company" as opposed to an "exporter".

Compared to proactiveness and innovativeness, risk-taking seemed to be less relevant for the case companies. For example, the manager from OIL noted that the firm is rather conservative in nature and tries to reduce risks:

People disagree with me on this, but primarily I think it's highly important that people have a plan to grow within their capacity. We're sitting in a recession at the moment, probably the world's worst in eighty years. We're in a position better than $99 \%$ of the companies in Australia primarily because we basically had no debt. We had a very 
good position with the bank. It's very attractive to get large orders when you start off, but they can be crippling. We had a philosophy of growing within ourselves and we've been able to maintain our standards as we've expanded exponentially. To me it's highly important to develop within yourself. It's very nice having huge goals and big targets. You should always have goals, but goals should be realistic and not put the company at risk. (OIL)

In general, the interviews revealed that the firms adopted a relatively "calculated" approach, and were thus characterised by a relatively low level of risk-taking. In addition, the managers noted that they prepared carefully for internationalisation. For example, the manager from MFG1 commented that the company established patents before going international:

From 2003 to 2006, we just set all our intellectual property rights, patents, trademarks, copyrights and so on and so forth. And basically prototyped and tested and broke and cracked and did everything to make sure that what we're going to bring to market was second to none. So we went global in 2006. (MFG1)

The manager from MFG1 explained the importance of setting up patents and intellectual property rights in order to get orders from large retailers:

And so big-box retailers are not going to invest money in products that they can't sell. And you actually, when you sign up with these companies, you have to sign a waiver to say that the product is registered, is patented, and that you are not infringing on anyone else's rights. So I definitely believe that that is a definite, strong point. (MFG1)

This comment demonstrates that patents were used as intangible knowledge assets to prepare for internationalisation, as has been identified previously in born globals by Mudambi and Zahra (2007).

In addition to exploring the literature-suggested aspects of international orientation, risk-taking, innovativeness and proactiveness, our qualitative approach allowed us to examine other emerging themes from our interviews. Passion was one such theme, which was raised frequently. For example, the managers from MFG1 and MFG2 commented:

I'm following a passion. I'm following a dream. And everything that I'm doing you can look at it from a, you know, textbook point of view. It's just something that's really 
just coming natural to me as a CEO... I'm an entrepreneur at heart. It's in my blood, it's in my family. My dad was an entrepreneur. He developed a range of products in his industry. And also did exactly what I'm doing worldwide. (MFG1)

I think it's just passion. About wanting to do the business. Basically, having the vision and passion to go offshore. (MFG2)

Another manager indicated that passion should be accompanied by business skills to ensure company success:

Entrepreneurs are driven by passion, but they often lack business skills. There are very few entrepreneurs that have both passion and business skills. If passion is complemented with business skills, then there will be successful entrepreneurs. (ICT2)

This suggests that passion by itself may not be sufficient for successful entrepreneurs. All of the interviewees demonstrated strong passion for their business, strong teams and good business skills within their firms, which were critical to success. As the manager from ICT1 noted, "my team is extremely passionate and absolutely hungry for success." If entrepreneurs lack business skills, the wider top management team or other external factors, such as business relationships, may play an important role in offering business skills.

The attribute of perseverance was also considered as an important driver for performing successfully in overseas markets. For example:

And perseverance. Very, very important. Without perseverance we would have given up a long time ago. Because it is very, very hard to break into international markets. But it's got to be a long-term plan. So that's some of the characteristics that you need. (MFG2)

You know, we're only about 5\% through of where I want to be. But I understand and I recognize and I'm getting to learn this a little bit more as I get a little bit older that there's no reason to sprint a marathon. But I'm not desperate to do anything. I want do it and execute it 100\% correctly. If I feel it's the right man for the job, then I'm prepared to wait. I mean I'm not into a quick fix. I'm into long-term strategic relationships. (MFG1) 
The metaphor in the quote above "There's no reason to sprint a marathon" from the MFG1 manager elegantly captures the dimension of perseverance and the associated long-term outlook. This suggests that understanding the "bigger picture" and putting in the necessary effort over time are important for these companies to succeed internationally, rather than looking for a quick fix. Patience and perseverance seem to be critical attributes for enduring challenging times. The key themes related to EO that evolved during the course of our interviews are summarised in Table 3.

Table 3 about here

$* * * * * * * * * * * * * * * * * * * * * * * * * * * * * * * * * * * * * * * * *$

$* * * * * * * * * * * * * * * * * * * * * * * * * * * * * * * * * * * * * * * *$

\section{Discussion}

The objectives of this study were to examine how entrepreneurial orientation is manifested in the context of born global firms. Specifically, we sought to identify whether or not the three dimensions of the Miller/Covin and Slevin EO scale - innovativeness, proactiveness and risktaking - were identifiable in born global firms. In addition, we investigated the potential of additional dimensions of EO, thus responding to Covin and Miller's (2014, p. 12) call for research on "unrecognized elements of EO/IEO".

Our interviews offered strong support for the importance of proactiveness as a component of entrepreneurial orientation. This is consistent with the literature and aligns with the INV model developed by Oviatt and McDougall (1994), which emphasises a proactive attitude and an opportunity-seeking strategic posture as key to INVs' successful, rapid internationalization. The literature suggests that proactiveness may yield several advantages for firms, ranging from first-mover advantages (Lyon et al., 2000) to superior business performance (Blesa and Ripollés, 2003; Frishammar and Andersson, 2009; Hughes and Morgan, 2007). Our interviewed firms displayed high levels of proactiveness and were, thus, 
active in the exploration of opportunities. As such, these firms appear to operate more as 'leaders' than 'followers' (Lumpkin and Dess, 1996).

Another EO dimension, innovativeness, received strong support in our interview data. Lumpkin and Dess (1996, p. 142) defined innovativeness as a "firm's tendency to engage in and support new ideas, novelty, experimentation, and creative processes that may result in new products, services, or technological processes”. Schumpeter (1934) identified it as lying at the heart of entrepreneurship. The firms in our study showed high levels of innovativeness, with respect to both technology and improving business processes. The interviewed managers stressed the importance of innovativeness for superior performance and competitive advantage, in order "not to get run over". These findings are consistent with the extant literature. For example, Lumpkin and Dess (1996) argued that young and small firms may depend more on innovativeness than older and larger companies. Innovativeness has also been linked to better firm performance (Calantone et al., 2002; Cho and Pucik, 2005; Hughes and Morgan, 2007; Hult et al., 2004). In a study of 211 high-technology UK firms, Hughes and Morgan (2007) examined the five dimensions of EO as developed by Lumpkin and Dess (1996), and reported a positive association between innovativeness and business performance. We obtained similar results in our interviews.

The third of the established EO dimensions, risk-taking, was of much less concern to the firms in our study. Defined as "the degree to which managers are willing to make large and risky resource commitments - i.e., those which have a reasonable chance of costly failures" (Miller and Friesen, 1978, p. 923), risk-taking is related to deciding on projects that are characterised by high potential losses. Our interviewees generally focused on reducing risk by carefully preparing for internationalisation.

While these findings differ from the traditional EO literature (e.g., Miller, 1983; Covin 
and Slevin, 1989), they are consistent with some more recent studies. Studying Australian born globals, Liesch et al. (2007) found that the firms tended to adopt confident, but cautious, strategies that were not overly risky, but rather based on a quiet confidence in their abilities by focusing on serving the needs of their overseas clients. As one born global manager noted, "don't put all your eggs in one basket and watch your costs" (Liesch et al., 2007, p. 24). Partnering with larger firms was used as a risk-minimising strategy. Some scholars (e.g., Hughes and Morgan, 2007) have pointed to the potential negative effects of risk-taking on performance, while Frishammar and Andersson (2009) reported no significant relationship between risk-taking and international performance, and concluded that small firms "cannot make any risky resource commitments when going international” $(2009$, p. 71$)$ and, therefore, may adopt internationalisation strategies with low levels of risk. This may be attributed to born globals' small resource base, such that costly failure would jeopardise survival. Morgan and Strong (2003) concluded that high-performing medium and large firms were distinctly cautious, and not characterised by risk-taking attitudes. Another potential explanation for the relatively low level of risk-taking in our sample firms may be related to the external environment; the interviews were conducted during the Global Financial Crisis, which may have shaped the risk-taking attitude of the born global managers; they may have adopted a more cautious attitude for their business activities, given the challenging developments in the external environment.

Our study also responds to Covin and Miller's (2014) recommendation for research on potential unrecognised elements of EO. The interviews revealed the importance of both perseverance and passion. Perseverance has been described as a necessary condition for being successful at starting and running entrepreneurial ventures (Baum and Locke, 2004), and relates to "continued goal striving in spite of adversity" (Van Gelderen, 2012, p. 630). 
According to Baum and Locke (2004, p. 588), perseverance involves "sustaining goaldirected action and energy even when faced with obstacles". In the entrepreneurship context, as individuals react differently to similar adverse situations, it has been proposed that the ability to persevere may determine the success of a new venture (Markman, et al., 2005). For example, perseverance has been found to have an indirect effect on venture growth (Baum and Locke, 2004), and linked to successful leadership (Kirkpatrick and Locke, 1991), on the basis that effective leaders have a "degree of strength of will or perseverance" (Bass 1990, p. 68). In addition, the determinants of perseverance in the business start-up phase have been examined in the literature, focusing on the role of entrepreneurs' cognitive orientation. For example, Gatewood, Shaver, and Gartner (1995) found that entrepreneurs who displayed internal/stable reasons for establishing their business ventures (e.g., "I've always wanted to have my own business") were more likely to persist in their actions that led to the successful creation of the new venture. Baron (2000) showed that entrepreneurs were significantly less likely to engage in counterfactual thinking ("What might have been?") in the venture formation process, and displayed significantly less regret over past actions, compared to nonentrepreneurs. Gatewood, Shaver, Powers, and Gartner (2002) examined the relationship between entrepreneurial expectancy and the effort-performance linkage. Their study provided evidence that the type of feedback (positive or negative) regarding entrepreneurial abilities changed the expectancies of future entrepreneurial performance, although not the level of effort to persevere on the entrepreneurial task (Gatewood et al., 2002). Operationalising perseverance as perceived control over adversity and responsibility for the outcome of adversity, Markman et al. (2005) found that entrepreneurs tended to have higher levels of perseverance than non-entrepreneurs. In addition, perseverance was positively related to annual earnings (Markman et al., 2005), thus potentially being a driver of an overall, albeit 
crude, measure of personal success.

As shown above, perseverance is related to the continued goal-striving in spite of adversities, and is, thus, linked to the survival of the firm. However, while perseverance is arguably necessary for survival, the literature indicates the primary need for critical business skills, especially in light of prior findings that the lack of appropriate management skills and poor financial management (e.g., inadequate accounting records and knowledge, lack of capital) are the two key causes of business failure (Hall and Young, 1991; Berryman, 1994). Our findings support this view. For example, the manager of ICT2 emphasized several times that "the first rule of business is to stay in business", and noted that many new companies fail because even though the entrepreneurs in the firms are passionate, they may lack the required business skills. The manager from MFG1 used the analogy of not "sprinting a marathon" in reference to the need for both perseverance and a strong business foundation. Thus, our interviews revealed that strong perseverance and a long-term strategic outlook are critical for born globals, in order to survive and prosper.

Passion was the second new dimension related to entrepreneurial orientation that was clear in our interviews. Interviewees described it as a fundamental posture that is necessary, in order to succeed in business. Similar to perseverance, participating managers noted that passion is a necessary, but not sufficient, component of business success, highlighting that, even though entrepreneurs are passionate, they may fail if they lack the necessary business skills. The role of passion has been emphasised in the popular press, with well-known leaders such as Steve Jobs noting that "Being the richest man in the cemetery doesn't matter to me. Going to bed at night saying, I've done something wonderful. That's what matters" (Gallo, 2011).

Entrepreneurial passion has been defined in the literature as "consciously accessible, 
intense positive feelings experienced by engagement in entrepreneurial activities associated with roles that are meaningful and salient to the self-identity of the entrepreneur" (Cardon et al., 2009, p. 517). In the psychology field, entrepreneurial passion has been conceptualised as a "strong inclination toward an activity that people like, that they find important, and in which they invest time and energy" (Vallerand et al., 2003, p. 757). Passion is an intense positive emotion, and has a motivational effect that stimulates entrepreneurs to overcome obstacles and remain engaged (Cardon et al., 2009). Smilor (1997, p. 342) noted passion as "perhaps the most observed phenomenon of the entrepreneurial process", and Ma and Tan (2006) argued that entrepreneurship is the embodiment of passion. Cardon et al. (2005) proposed the parenthood metaphor, by describing entrepreneurship as a "parent and child" relationship in which the entrepreneur feels a sense of attachment and identification with his/her own venture that is analogous to the parenting process. As a result, values such as passion, identification, attachment and nurturing, as well as fear, rejection and regret, are key attributes of the entrepreneurship process (Cardon et al., 2005).

However, despite the importance of passion for entrepreneurs, it has been argued that entrepreneurial passion has not been studied systematically and existing research is generally fragmented (Cardon et al., 2009; Shane et al., 2003). In particular, there are few empirical studies dealing with passion among entrepreneurs (Shane et al., 2003). Passion has been found to have an indirect positive relationship with venture growth, mediated by variables such as vision, goals, self-efficacy, competency, motivation, and competitive strategy (Baum and Locke, 2004; Baum et al., 2001). Passion has also been linked to enabling greater opportunity recognition, idea development, and opportunity execution (Shane et al., 2003; Baron and Ward, 2004). In our interviews, passion was perceived as a sine qua non an indispensable "must-have", in order to be successful. The managers were "naturally 
passionate" about their business (e.g., the interviewee from MFG1 noted that he is following a passion and a dream), while several managers likened their companies to "a small family", lending support to the "parenthood metaphor" of Cardon et al. (2005). Based on our empirical findings, we propose that researchers consider incorporating perseverance and passion as new elements of EO as they are conceptually distinct from the dimensions of proactiveness, innovativeness, and risk-taking.

\section{Limitations and future research}

Our qualitative methodology is a strength, in that it provided us with rich data that allowed an in-depth examination of how EO is manifested in born globals, along with exploration of potential additional dimensions of EO for born global firms. However, the small number of cases makes our findings tentative in nature. In addition, the limited geographical context of Australia and New Zealand may not be representative of born globals in other parts of the world. The timing of our interviews, in the midst of the global financial crisis, could also have suppressed the level of risk taking of the firms in our sample.

Future research studies, with larger size samples and with born global firms from other parts of the world, and at a different point in time are needed. In addition, future studies may investigate how EO is present in born globals that are using various entry modes, thus responding to Covin and Miller's (2014) suggestion that differences in investment strategies (e.g. overseas manufacturing vs. exporting) may affect the dimensions of EO. Covin and Miller (2014) called this the "cascading effect" of EO. Another potential future research area relates to the role of international trade shows as a manifestation of proactiveness. In this regard, further investigation into the motives for using trade shows and the dynamics on how trade shows are being effectively utilised by born globals may represent worthy avenues for 
future research.

\section{Concluding remarks}

This is one of the few studies that delves deeply into the EO construct as it relates to born global firms; in doing so, we add to the theoretical understanding of the construct. Our study found strong support for the EO dimensions of proactiveness and innovativeness among these rapidly-internationalising firms. Risk-taking was present, albeit to a lesser degree, as the born global firms in our sample were generally relatively conservative, and in several cases, actively sought to reduce risk. Thus, contrary to most studies of EO, we found that risk-taking was not necessarily manifest alongside proactiveness and innovativeness. Consistent with Dai et al. (2014), this suggests that a multidimensional measure of the EO construct, which accounts for the dimensions separately, might be more useful than the aggregated measure associated with the Miller/Covin \& Slevin (1989) scale. Further, the support that we found for the additional dimensions of perseverance and passion sheds light on EO in the context of born global firms, contributing to the IE literature. Specifically, our findings suggest that these two dimensions merit consideration as part of the EO construct, as separately-measured dimensions of the construct. We hope that future research will build on our exploratory study and further advance our understanding of EO, which is arguably an essential component for born global firms. 


\section{References}

Andersson, S. (2000), "The internationalization of the firm from an entrepreneurial perspective", International Studies of Management \& Organization, Vol. 30 No. 1, pp. 63-92.

Andersson, S., Evers, N., and Griot, C. (2013), "Local and international networks in small firm internationalization: Cases from the Rhône-Alpes medical technology regional cluster", Entrepreneurship \& Regional Development, Vol. 25 No. 9/10, pp. 867-888.

Baron, R. A. (2000), "Counterfactual thinking and venture formation: The potential effects of thinking about "what might have been”, Journal of Business Venturing, Vol. 15 No. 1, pp. 79-91.

Baron, R. A. and Ward, T. B. (2004), "Expanding entrepreneurial cognition's toolbox: Potential contributors from the field of cognitive science", Entrepreneurship Theory and Practice, Vol. 28 , pp. 553-573.

Bass, B.M. (1990), Bass \& Stogdill's handbook of leadership: Theory, research, and managerial applications. The Free Press, New York.

Baum, J. R., Locke, E. A. and Smith, K. G. (2001), “A multidimensional model of venture growth”, Academy of Management Journal, Vol. 44, pp. 292-303.

Baum, J. R., and Locke, E. A. (2004), "The relationship of entrepreneurial traits, skill, and motivation to subsequent venture growth", Journal of Applied Psychology, Vol. 89 No. 4, pp. 587-598.

Bernard, H. R. (2006), Research methods in anthropology: Qualitative and quantitative approaches, AltaMira Press, Oxford.

Berryman, J. E. (1994), "Small business failure and bankruptcy: What progress has been made in a decade?", Small Enterprise Research, Vol. 2 No. 1-2, pp. 5-27.

Bickerdyke, I., Lattimore, R. and Madge, A. (2000), Business failure and change: An Australian perspective, Productivity Commission Staff Research Paper, Canberra.

Blesa, A., and Ripollés, M. (2003), "The role of market orientation in the relationship between entrepreneurial proactiveness and performance", Journal of Entrepreneurship, Vol. 12 No. 1, pp. 1-19.

Boso, N., Story, V. M. and Cadogan, J. W. (2013), "Entrepreneurial orientation, market orientation, network ties, and performance: Study of entrepreneurial firms in a developing economy", Journal of Business Venturing, Vol. 28 No. 6, pp. 708-727.

Calantone, R. J., Cavusgil, S. T. and Zhao, Y. (2002), "Learning orientation, firm innovation capability, and business performance", Industrial Marketing Management, Vol. 31, pp. 515-524.

Cardon, M. S., Zietsma, C., Saparito, P., Matherne, B. P. and Davis, C. (2005), “A tale of passion: New insights into entrepreneurship from a parenthood metaphor", Journal of Business Venturing, Vol. 20 No.1, pp. 23-45. 
Cardon, M. S., Wincent, J., Singh, J. and Drnovsek, M. (2009), "The nature and experience of entrepreneurial passion", Academy of Management Review, Vol. 34 No. 3, pp. 511-532.

Cavusgil, S. T. and Knight, G. (2009), Born global firms: A new international enterprise, Business Expert Press, New York.

Cho, H.-J. and Pucik, V. (2005), "Relationship between innovativeness, quality, growth, profitability, and market value." Strategic Management Journal, Vol. 26 No. 6, pp. 555-575.

Coviello, N. E., McDougall, P.P. and Oviatt, B. M. (2011), "The emergence, advance and future of international entrepreneurship research", Journal of Business Venturing, Vol. 26 No. 6, pp. 625-631.

Covin, J. G. and Miller, D. (2014), "International entrepreneurial orientation: Conceptual considerations, research themes, measurement issues, and future research directions", Entrepreneurship Theory and Practice, Vol. 38 No. 1, pp. 11-44.

Covin, J. G. and Lumpkin, G. T. (2011), "Entrepreneurial orientation theory and research: Reflections on a needed construct", Entrepreneurship Theory and Practice, Vol. 35 No. 5, pp. 855-872.

Covin, J. G. and Slevin, D. P. (1989), "Strategic management of small firms in hostile and benign environments", Strategic Management Journal, Vol. 10 No. 1, pp. 75-87.

Covin, J. G. and Wales, W. (2012), "The measurement of entrepreneurial orientation", Entrepreneurship Theory and Practice, Vol. 36 No. 4, pp. 677-702.

Dai, L, Maksimov, V., Gilbert, B. A. and Fernhaber, S. A. (2014), "Entrepreneurial orientation and international scope: The differential roles of innovativeness, proactiveness, and risk-taking", Journal of Business Venturing, Vol. 25 No. 4, pp. 511-524.

Eisenhardt, K. M. (1989), "Building theories from case study research", Academy of Management Review, Vol. 14 No. 4, pp. 532-550.

Fatehi, K. and Ghadar, F. (2014), “A measure of international managers' mindset”, International Journal of Commerce and Management, Vol. 24 No. 4, pp. 321-333.

Fletcher, D. (2004), "International entrepreneurship and the small business", Entrepreneurship \& Regional Development, Vol. 16 No. 4, pp. 289-305.

Freeman, S. and Cavusgil, S. T. (2007), "Toward a typology of commitment states among managers of born-global firms: A study of accelerated internationalization”, Journal of International Marketing, Vol. 15 No. 4, pp. 1-40.

Frishammar, J. and Andersson, S. (2009), "The overestimated role of strategic orientations for international performance in smaller firms", Journal of International Entrepreneurship, Vol. 7 No. 1, pp. 57-77. 
Gallo, C. (2011), “Steve Jobs: What makes your heart sing?", available at http://www.forbes.com/sites/carminegallo/2011/10/10/steve-jobs-what-makes-your-heartsing/ (accessed 10 May 2016).

Gatewood, E. J., Shaver, K. G. and Gartner, W. B. (1995), “A longitudinal study of cognitive factors influencing start-up behaviors and success at venture creation”, Journal of Business Venturing, Vol. 10, pp. 371-391.

Gatewood, E. J., Shaver, K. G., Powers, J. B. and Gartner, W. B. (2002), “Entrepreneurial expectancy, task effort, and performance", Entrepreneurship Theory and Practice, Vol. 27 No. 2, pp. 187206.

Gerschewski, S., Rose, E. L. and Lindsay, V. J. (2015), "Understanding the drivers of international performance for born global firms: An integrated perspective”, Journal of World Business, Vol. 50 No. 3, pp. 558-575.

Glaser, B. G. and Strauss, A. L. (1967), The discovery of grounded theory: Strategies for qualitative research, Aldine Publishing Company, Chicago.

Guest, G., Bunce, A. and Johnson, A. (2004), "How many interviews are enough? An experiment with data saturation and variability", Field Methods, Vol. 18 No. 1, pp. 59-82.

Hall, G. and Young, B. (1991), "Factors associated with insolvency amongst small firms", International Small Business Journal, Vol. 9 No. 2, pp. 54-63.

Hughes, M. and Morgan, R. E. (2007), "Deconstructing the relationship between entrepreneurial orientation and business performance at the embryonic stage of firm growth", Industrial Marketing Management, Vol. 36 No. 5, pp. 651-661.

Hult, G. T. M., Hurley, R. F. and Knight, G. A. (2004), "Innovativeness: Its antecedents and impact on business performance”, Industrial Marketing Management, Vol. 33 No. 5, pp. 429-438.

Ibeh, K. I. N. and Young, S. (2001), "Exporting as an entrepreneurial act - An empirical study of Nigerian firms", European Journal of Marketing, Vol. 3 No. 5/6, pp. 566-586.

Jambulingam, T., Kathuria, R. and Doucette, W. R. (2005), "Entrepreneurial orientation as a basis for classification within a service industry: The case of retail pharmacy industry", Journal of Operations Management, Vol. 23, pp. 23-42.

Jantunen, A., Puumalainen, Kl, Saarenketo, S. and Kyläheiko, K. (2005), "Entrepreneurial orientation, dynamic capabilities, and international performance", Journal of International Entrepreneurship, Vol. 3 No. 3, pp. 222-243.

Jantunen, A., Nummela, N., Puumalainen, K. and Saarenketo, S. (2008), "Strategic orientations of born globals - Do they really matter?”, Journal of World Business, Vol. 43 No. 2, pp. 158-170.

Jaworski, B. J. and Kohli, A. K. (1993), "Market orientation: Antecedents and consequences”, Journal of Marketing, Vol. 57 No. 3, pp. 53-70. 
Joardar, A. and Wu, S. (2011), "Examining the dual forces of individual entrepreneurial orientation and liability of foreignness on international entrepreneurs", Canadian Journal of Administrative Sciences, Vol. 28 No. 3, pp. 328-340.

Jolly, V., Alahuhta, M. and Jeannet, J.-P. (1992), “Challenging the incumbents: How high technology start-ups compete globally", Journal of Strategic Change, Vol. 1 No. 2: pp. 71-82.

Jones, M. V. and Coviello, N. (2005), "Internationalisation: Conceptualising an entrepreneurial process of behaviour in time", Journal of International Business Studies, Vol. 36 No. 3, pp. 284-303.

Jones, M. V., Coviello, N. and Tang, Y. K. (2011), "International entrepreneurship research (19892009): A domain ontology and thematic analysis", Journal of Business Venturing, Vol. 26 No. 6, pp. 632-659.

Karra, N., Phillips, N. and Tracey, P. (2008), "Building the born global firm: Developing entrepreneurial capabilities for international new venture success", Long Range Planning, Vol. 41 No. 4, pp. 440-458.

Keupp, M. M. and Gassmann, O. (2009), "The past and the future of international entrepreneurship: A review and suggestions for developing the field", Journal of Management, Vol. 35 No. 3, pp. 600-633.

Khandwalla, P. (1977), The Design of Organizations. Harcourt Brace Jovanovich, New York.

Kirkpatrick, S. A. and Locke, E. A. (1991), “Leadership: Do traits matter?”, Academy of Management Executive, Vol. 5 No. 2, pp. 48-60.

Knight, G. A. (2001), "Entrepreneurship and strategy in the international SME", Journal of International Management, Vol. 7 No. 3, pp. 155-171.

Knight, G. A. and Cavusgil, S. T. (2004), "Innovation, organizational capabilities, and the born-global firm”, Journal of International Business Studies, Vol. 35 No. 2, pp. 121-141.

Knight, G. A. and Kim, D. (2009), "International business competence and the contemporary firm", Journal of International Business Studies, Vol. 40 No. 2, pp. 255-273.

Kocak, A. and Abimbola, T. (2009), "The effects of entrepreneurial marketing on born global performance", International Marketing Review, Vol. 26 No. 4/5, pp. 439-452.

Kropp, F., Lindsay, N. J. and Shoham, A. (2008), "Entrepreneurial orientation and international entrepreneurial business venture startup", International Journal of Entrepreneurial Behaviour \& Research, Vol. 14 No. 2, pp. 102-117.

Kuivalainen, O., Sundquist, S., Puumalainen, K. and Cadogan, J. W. (2004), "The effect of environmental turbulence and leader characteristics on international performance: Are knowledge-based firms different?", Canadian Journal of Administrative Sciences, Vol. 21 No. 1, pp. 35-50. 
Kuivalainen, O., Sundqvist, S. and Servais, P. (2007), "Firms' degree of born-globalness, international entrepreneurial orientation and export performance", Journal of World Business, Vol. 42 No. 3, pp. 253-267.

Kuzel, A. (1992), "Sampling in qualitative inquiry", in Crabtree, B. and Miller, W. (Eds.) Doing qualitative research, Sage, Newbury Park, CA, pp. 31-44.

Liesch, P., Steen, M., Middleton, S. and Weerawardena, J. (2007), Born to be global: A closer look at the international venturing of Australian born global firms, Australian Business Foundation, Sydney.

Lindsay, V. J. (2004), “Computer-assisted qualitative data analysis: Application in an export study”, in by Marschan-Piekkari, R. and Welch, C. (Eds.) Handbook of qualitative research methods for international business, Edward Elgar, Cheltenham, pp. 486-506.

Lumpkin, G. T. and Dess, G. G. (1996), "Clarifying the entrepreneurial orientation construct and linking it to performance", Academy of Management Review, Vol. 21 No. 1, pp. 135-172.

Lyon, D.W., Lumpkin, G.T. and Dess, G. G. (2000), "Enhancing entrepreneurial orientation research: Operationalizing and measuring a key strategic decision making process", Journal of Management, Vol. 26 No. 5, pp. 1055-1085.

Ma, H. and Tan, J. (2006), "Key components and implications of entrepreneurship: A 4-P framework", Journal of Business Venturing, Vol. 21, pp. 704-725.

Markman, G. D., Baron, R. A. and Balkin, D. B. (2005), “Are perseverance and self-efficacy costless? Assessing entrepreneurs' regretful thinking”, Journal of Organizational Behavior, Vol. 26, pp. $1-19$.

McAuley, A. (1999), "Entrepreneurial instant exporters in the Scottish arts and crafts sector", Journal of International Marketing, Vol. 7 No. 4, pp. 67-82.

McDougall, P. P. (1989), "International versus domestic entrepreneurship: New venture strategic behavior and industry structure", Journal of Business Venturing, Vol. 4, pp. 387-399.

McDougall, P. P., and Oviatt, B. M. (2000), "International entrepreneurship: The intersection of two research paths", Academy of Management Journal, Vol. 43 No. 5, pp. 902-906.

Miles, M. B. and Huberman, A. M. (1994), Qualitative data analysis: An expanded sourcebook, Sage, Thousand Oaks.

Miller, D. (1983), “The correlates of entrepreneurship in three types of firms", Management Science, Vol. 29 No. 7, pp. 770-791.

Miller, D. and Friesen, P. H. (1978), “Archetypes of strategy formulation”, Management Science, Vol. 24 No. 9, pp. 921-933.

Miller, D. and Friesen, P. H. (1984), Organizations: A Quantum View, Prentice Hall, Englewood Cliffs, NJ. 
Morgan, R. E. and Strong, C. A. (2003), "Business performance and dimensions of strategic orientation." Journal of Business Research, Vol. 56 No. 3, pp. 163-176.

Morse, J. M. (2005), "Evolving trends in qualitative research: Advances in mixed-method design", Qualitative Health Research, Vol. 15 No. 5, pp. 583-585.

Mort, G. S. and Weerawardena, J. (2006), "Networking capability and international entrepreneurship How networks function in Australian born global firms", International Marketing Review, Vol. 23 No. 5 , pp. 549-572.

Mostafa, R. H. A., Wheeler, C. and Jones, M. V. (2006), "Entrepreneurial orientation, commitment to the internet and export performance in small and medium sized exporting firms", Journal of International Entrepreneurship, Vol. 3 No. 4, pp. 291-302.

Mudambi, R. and Zahra, S. A. (2007), "The survival of international new ventures", Journal of International Business Studies, Vol. 38 No. 2, pp. 333-352.

Naman, J. L. and Slevin, D. P. (1993), "Entrepreneurship and the concept of fit: A model and empirical tests", Strategic Management Journal, Vol. 14 No. 2, pp. 137-154.

Narver, J. C. and Slater, S. F. (1990), "The effect of a market orientation on business profitability", Journal of Marketing, Vol. 54 No. 4, pp. 20-35.

Oviatt, B. M. and McDougall, P. P. (1994), "Toward a theory of international new ventures", Journal of International Business Studies, Vol. 25 No. 1, pp. 45-64.

Oviatt, B. M. and McDougall, P. P. (2005), “The internationalization of entrepreneurship", Journal of International Business Studies, Vol. 36 No. 1, pp. 2-8.

Pinfold, J. F. (2000), "Examining new venture failure rates: A New Zealand study”, Small Enterprise Research, Vol. 8 No. 1, pp. 56-72.

Rauch, A., Wiklund, J., Lumpkin, G.T. and Frese, M. (2009), "Entrepreneurial orientation and business performance: An assessment of past research and suggestions for the future", Entrepreneurship Theory and Practice, Vol. 33 No. 3, pp. 761-787.

Rennie, M. W. (1993), “Born global”, McKinsey Quarterly, Vol. 4, pp. 45-52.

Ripollés-Méliá, M., Menguzzato-Boulard, M. and Sánchez-Peinado, L. (2007), "Entrepreneurial orientation and international commitment", Journal of International Entrepreneurship, Vol. 5 No. 3-4, pp. 65-83.

Schumpeter, J. A. (1934), The theory of economic development, Harvard University Press, Cambridge, MA.

Shane, S., Locke, E. A. and Collins, C. J. (2003), "Entrepreneurial motivation", Human Resource Management Review, Vol. 13, pp. 257-279. 
Sinkovics, R. R., Penz, E. and Ghauri, P. N. (2008), "Enhancing the trustworthiness of qualitative research in international business", Management International Review, Vol. 48 No. 6, pp. 689-714.

Slevin, D. P. and Terjesen, S. J. (2011), "Entrepreneurial orientation: Reviewing three papers and implications for further theoretical and methodological development", Entrepreneurship Theory and Practice, Vol. 35 No. 5, pp. 973-987.

Smart, D. T. and Conant, J. S. (1994), "Entrepreneurial orientation, distinctive marketing competencies and organizational performance", Journal of Applied Business Research, Vol. 10 No. 3, pp. $18-28$.

Smilor, R. W. (1997), "Entrepreneurship: Reflections on a subversive activity”, Journal of Business Venturing, Vol. 12, pp. 341-346.

Statistics New Zealand (2008), "New Zealand business demography statistics", available at http://www.stats.govt.nz/browse_for_stats/businesses/business_characteristics/businessdemog raphystatistics_mrfeb07s.aspx. (accessed 10 April 2016).

Stewart, W. H. J., Watson, W. E., Carland, J. E. and Carland, J. W. (1999), “A proclivity for entrepreneurship: A comparison of entrepreneurs, small business owners, and corporate managers," Journal of Business Venturing, Vol. 14 No. 2, pp. 189-214.

Sundqvist, S., Kyläheiko, K., Kuivalainen, O. and Cadogan, J. W. (2012), "Kirznerian and Schumpeterian entrepreneurial-oriented behavior in turbulent export markets", International Marketing Review, Vol. 29 No. 2, pp. 203-219.

Vallerand, R. J., Blanchard, C., Mageau, G. A., Koestner, R., Ratelle, C. F., Léonard, M., Gagné, M. and Marsolais, J. (2003), "Les passions de l'âme: On obsessive and harmonious passion", Journal of Personality and Social Psychology, Vol. 85: pp. 756-767.

Van Gelderen, M. (2012), "Perseverance strategies of enterprising individuals", International Journal of Entrepreneurial Behaviour \& Research, Vol. 18, No. 6, pp. 630-648.

Van Geenhuizen, M. (2008), "Knowledge networks of young innovators in the urban economy: Biotechnology as a case study", Entrepreneurship \& Regional Development, Vol. 20 No. 2, pp. 161-183.

Wales, W. J. (2016), "Entrepreneurial orientation: A review and synthesis of promising research directions", International Small Business Journal, Vol. 34 No. 1, pp. 3-15.

Weerawardena, J., Mort, G. S. Liesch, P. W. and Knight, G. (2007), "Conceptualizing accelerated internationalization in the born global firm: A dynamic capabilities perspective", Journal of World Business, Vol. 42 No. 3, pp. 294-306.

Wiklund, J. (1998), Small firm growth and performance: Entrepreneurship and beyond. Unpublished doctoral dissertation, Jönköping International Business School, Jönköping. 
Zhang, X., Ma, X., and Wang, Y. (2012), "Entrepreneurial orientation, social capital, and the internationalization of SMEs: Evidence from China", Thunderbird International Business Review, Vol. 54 No. 2, pp. 195-210.

Zhang, M., Tansuhaj, P. and McCullough, J. (2009), "International entrepreneurial capability: The measurement and comparison between born global firms and traditional importers in China", Journal of International Entrepreneurship, Vol. 7 No. 4, pp. 292-322.

Zhou, L. (2007), "The effects of entrepreneurial proclivity and foreign market knowledge on early internationalization", Journal of World Business, Vol. 42 No. 3, pp. 281-293. 
Table 1: The measurement of EO and IEO in the context of born globals/INVs

\begin{tabular}{|c|c|c|c|c|}
\hline Author & EO or IEO & Definition of EO/IEO & $\begin{array}{l}\text { Operationalisation } \\
\text { of EO/IEO }\end{array}$ & Journal* \\
\hline Knight (2001) & IEO & $\begin{array}{l}\text { "International entrepreneurial orientation is } \\
\text { a fundamental corporate posture, } \\
\text { contributing strongly to the international } \\
\text { performance of the SME. It emphasizes } \\
\text { innovation, risk taking, and a generally } \\
\text { proactive approach to business in foreign } \\
\text { markets." (p. 159) }\end{array}$ & $\begin{array}{l}8 \text { items adapted from } \\
\text { Khandwalla (1977), } \\
\text { Covin \& Slevin } \\
\text { (1989); Miller \& } \\
\text { Friesen (1984) }\end{array}$ & JIM \\
\hline $\begin{array}{l}\text { Ibeh \& Young } \\
(2001)\end{array}$ & $\begin{array}{l}\text { Export- } \\
\text { entrepreneurial } \\
\text { orientation }\end{array}$ & $\begin{array}{l}\text { "Export-related innovativeness (i.e. the } \\
\text { extent to which they pursue new product } \\
\text { ideas for export, consider new export } \\
\text { markets, seek new information on } \\
\text { exporting); proactiveness (nature of } \\
\text { motivations regarding exporting, search for } \\
\text { export information, attendance at local/ } \\
\text { foreign trade fairs); and risk taking } \\
\text { (perceptions of exporting risks versus } \\
\text { opportunities, relative focus on domestic } \\
\text { versus export markets, relative emphasis on } \\
\text { current export returns versus long-term } \\
\text { marketing objectives)." (p. 570) }\end{array}$ & $\begin{array}{l}10 \text { items } \\
\text { Proactiveness } \\
\text { Innovativeness } \\
\text { Risk-taking }\end{array}$ & EJM \\
\hline
\end{tabular}

\begin{tabular}{|c|c|c|c|c|}
\hline $\begin{array}{l}\text { Knight \& } \\
\text { Cavusgil } \\
\text { (2004) }\end{array}$ & IEO & $\begin{array}{l}\text { "International entrepreneurial orientation } \\
\text { reflects the firm's overall innovativeness } \\
\text { and proactiveness in the pursuit of } \\
\text { international markets. It is associated with } \\
\text { innovativeness, managerial vision, and } \\
\text { proactive competitive posture."(p. 129) }\end{array}$ & $\begin{array}{l}12 \text { items adapted from } \\
\text { Khandwalla (1977) } \\
\text { and Covin \& Slevin } \\
\text { (1989) }\end{array}$ & JIBS \\
\hline $\begin{array}{l}\text { Mostafa et al. } \\
(2006)\end{array}$ & EO & & $\begin{array}{l}9 \text { item scale as } \\
\text { developed by Covin } \\
\& \text { Slevin (1989) } \\
\text { Proactiveness } \\
\text { Innovativeness } \\
\text { Risk-taking }\end{array}$ & JIE \\
\hline
\end{tabular}

\begin{tabular}{|c|c|c|c|c|}
\hline $\begin{array}{l}\text { Freeman \& } \\
\text { Cavusgil } \\
(2007)\end{array}$ & IEO & $\begin{array}{l}\text { "International entrepreneurial orientation re } \\
\text { fers to the behavioral elements of a globalo } \\
\text { rientation and captures top management's p } \\
\text { ropensity for risk taking, innovativeness, an } \\
\text { d proactiveness" (p. 3) }\end{array}$ & $\begin{array}{l}\text { Qualitative study: } \\
\text { Proactiveness } \\
\text { Innovativeness } \\
\text { Risk-taking }\end{array}$ & JIMKTG \\
\hline $\begin{array}{l}\text { Ripollés- } \\
\text { Mélia et al. } \\
(2007)\end{array}$ & $\mathrm{EO}$ & & $\begin{array}{l}9 \text { item scale as } \\
\text { developed by Covin } \\
\text { \& Slevin (1989) } \\
\text { Proactiveness } \\
\text { Innovativeness } \\
\text { Risk-taking }\end{array}$ & JIE \\
\hline Zhou (2007) & $\begin{array}{l}\text { International } \\
\text { entrepreneurial } \\
\text { proclivity }\end{array}$ & & $\begin{array}{l}\text { 14-item scale adapted } \\
\text { from Covin \& Slevin } \\
\text { (1989); Lumpkin \& } \\
\text { Dess (1996); Smart \& }\end{array}$ & JWB \\
\hline
\end{tabular}




\begin{tabular}{|c|c|c|c|c|}
\hline $\begin{array}{l}\text { Jantunen et al. } \\
\text { (2008) }\end{array}$ & EO & & $\begin{array}{l}9 \text { items adapted from } \\
\text { Naman \& Slevin } \\
\text { (1993) and Wiklund } \\
\text { (1998) }\end{array}$ & JWB \\
\hline $\begin{array}{l}\text { Kropp et al. } \\
(2008)\end{array}$ & IEO & $\begin{array}{l}\text { Proactiveness, innovativeness and } \\
\text { risk-taking }\end{array}$ & $\begin{array}{l}\text { 15-item scale adapted } \\
\text { from Covin \& Slevin } \\
\text { (1989); } \\
\text { Khandwalla (1977); } \\
\text { Miller \& Friesen } \\
\text { (1984); Lumpkin \& } \\
\text { Dess (1996) }\end{array}$ & IJEBR \\
\hline
\end{tabular}

\begin{tabular}{|c|c|c|c|}
\hline $\begin{array}{l}\text { Knight \& Kim } \\
\text { (2009) }\end{array}$ & $\begin{array}{l}\text { International } \\
\text { orientation }\end{array}$ & $\begin{array}{l}11 \text { items adapted from } \\
\text { Khandwalla (1977), } \\
\text { Covin \& Slevin } \\
\text { (1989); Miller \& } \\
\text { Friesen (1984) }\end{array}$ & JIBS \\
\hline $\begin{array}{l}\text { Frishammar \& } \\
\text { Andersson } \\
\text { (2009) }\end{array}$ & EO & $\begin{array}{l}\text { 9-item scale as } \\
\text { developed by Covin } \\
\text { \& Slevin (1989) } \\
\text { Proactiveness } \\
\text { Innovativeness } \\
\text { Risk-taking }\end{array}$ & JIE \\
\hline
\end{tabular}

\begin{tabular}{l|lll}
$\begin{array}{l}\text { Sundqvist et } \\
\text { al. (2012) }\end{array}$ & IEO & $\begin{array}{l}\text { "A set of behaviors associated with the } \\
\text { potential creation of value, which manifest } \\
\text { themselves as proactive and innovative } \\
\text { methods, risk-taking activity, autonomous } \\
\text { actions, and an emphasis on outperforming } \\
\text { rivals, all variously aimed at discovering, } \\
\text { enacting, evaluating, and exploiting } \\
\text { opportunities across national borders." } \\
\text { (p. 205) }\end{array}$ & $\begin{array}{l}\text { Proactiveness, } \\
\text { innovativeness, } \\
\text { risk-taking, and } \\
\text { autonomy items } \\
\text { adapted from } \\
\text { Jambulingam et al. } \\
\text { (2005) } \\
\text { Competitive } \\
\text { aggressiveness items } \\
\text { adapted from Narver }\end{array}$ \\
\hline
\end{tabular}




\begin{tabular}{|c|c|c|c|c|}
\hline Author & EO or IEO & Definition of EO/IEO & $\begin{array}{l}\text { Operationalisation } \\
\text { of EO/IEO }\end{array}$ & Journal* \\
\hline & & & $\begin{array}{l}\text { \& Slater (1990) and } \\
\text { Jaworski \& Kohli } \\
\text { (1993) }\end{array}$ & \\
\hline $\begin{array}{l}\text { Boso et al. } \\
\text { (2013) }\end{array}$ & $\mathrm{EO}$ & & $\begin{array}{l}13 \text { items based on } \\
\text { Lumpkin \& Dess } \\
\text { (1996), Covin \& } \\
\text { Slevin (1989), } \\
\text { Jambulingam et al. } \\
\text { (2012) }\end{array}$ & JBV \\
\hline $\begin{array}{l}\text { Dai et al. } \\
\text { (2014) }\end{array}$ & $\mathrm{EO}$ & & $\begin{array}{l}\text { 9-item scale as } \\
\text { developed by Covin } \\
\text { \& Slevin (1989) }\end{array}$ & JBV \\
\hline
\end{tabular}

*JIM=Journal of International Management EJM=European Journal of Marketing JIBS $=$ Journal of International Business Studies $\mathrm{JIE}=\mathrm{J}$ ournal of International Entrepreneurship JIMKTG =Journal of International Marketing $J W B=$ Journal of World Business IJEBR=International Journal of Entrepreneurial Behaviour \& Research IMR $=$ International Marketing Review $\mathrm{JBV}=$ Journal of Business Venturing 
Table 2: Profile of interviewed companies ${ }^{1}$

\begin{tabular}{|c|c|c|c|c|c|c|c|c|}
\hline & FOOD & ICT1 & ICT2 & EDUC & OIL & WINE & MFG1 & MFG2 \\
\hline $\begin{array}{l}\text { Number of } \\
\text { employees }\end{array}$ & 15 & 70 & 75 & 32 & 50 & 8 & 15 & 42 \\
\hline Industry & Food & $\mathrm{ICT}$ & ICT & Education & $\begin{array}{l}\text { Oil and } \\
\text { Gas }\end{array}$ & Wine & $\begin{array}{l}\text { Manu- } \\
\text { facturing }\end{array}$ & $\begin{array}{l}\text { Manu- } \\
\text { facturing }\end{array}$ \\
\hline $\begin{array}{l}\text { Year of } \\
\text { establishment }\end{array}$ & 2001 & 2001 & 1999 & 2003 & 2002 & 1998 & 2003 & 1994 \\
\hline $\begin{array}{l}\text { Year of first } \\
\text { internatio- } \\
\text { nalisation }\end{array}$ & 2003 & 2002 & 2001 & 2005 & 2003 & 1998 & 2006 & 1997 \\
\hline $\begin{array}{l}\text { International } \\
\text { sales ratio } \\
\text { three years } \\
\text { after firm } \\
\text { establishment }\end{array}$ & $60 \%$ & $99 \%$ & $98 \%$ & $51 \%$ & $50 \%$ & $75 \%$ & $40 \%$ & $30 \%$ \\
\hline $\begin{array}{l}\text { First main } \\
\text { international } \\
\text { markets }\end{array}$ & $\begin{array}{l}\text { USA, } \\
\text { Australia, } \\
\text { Singapore }\end{array}$ & $\begin{array}{l}\text { Korea, } \\
\text { USA, UK, } \\
\text { Japan, } \\
\text { Taiwan }\end{array}$ & France & $\begin{array}{l}\text { Singapore } \\
\text { Canada }\end{array}$ & $\begin{array}{l}\text { Middle } \\
\text { East }\end{array}$ & $\begin{array}{l}\text { USA, UK, } \\
\text { Europe }\end{array}$ & $\begin{array}{l}\text { Hong } \\
\text { Kong, } \\
\text { Singapore } \\
\text { UK, USA, } \\
\text { Taiwan }\end{array}$ & $\begin{array}{l}\text { USA, UK, } \\
\text { Australia }\end{array}$ \\
\hline $\begin{array}{l}\text { Entry mode } \\
\text { to first main } \\
\text { international } \\
\text { markets }^{2}\end{array}$ & Export & $\begin{array}{l}\text { Export, } \\
\text { WOS(M) }\end{array}$ & Export & $\begin{array}{l}\text { Export, } \\
\text { Strategic } \\
\text { alliance }\end{array}$ & $\begin{array}{l}\text { Export, } \\
\text { Joint } \\
\text { venture }\end{array}$ & Export & $\begin{array}{l}\text { Export, } \\
\text { WOS(S) }\end{array}$ & $\begin{array}{l}\text { Licensing, } \\
\text { Export, } \\
\text { Strategic } \\
\text { alliance }\end{array}$ \\
\hline
\end{tabular}


Figure 1: Coding structure for interviews
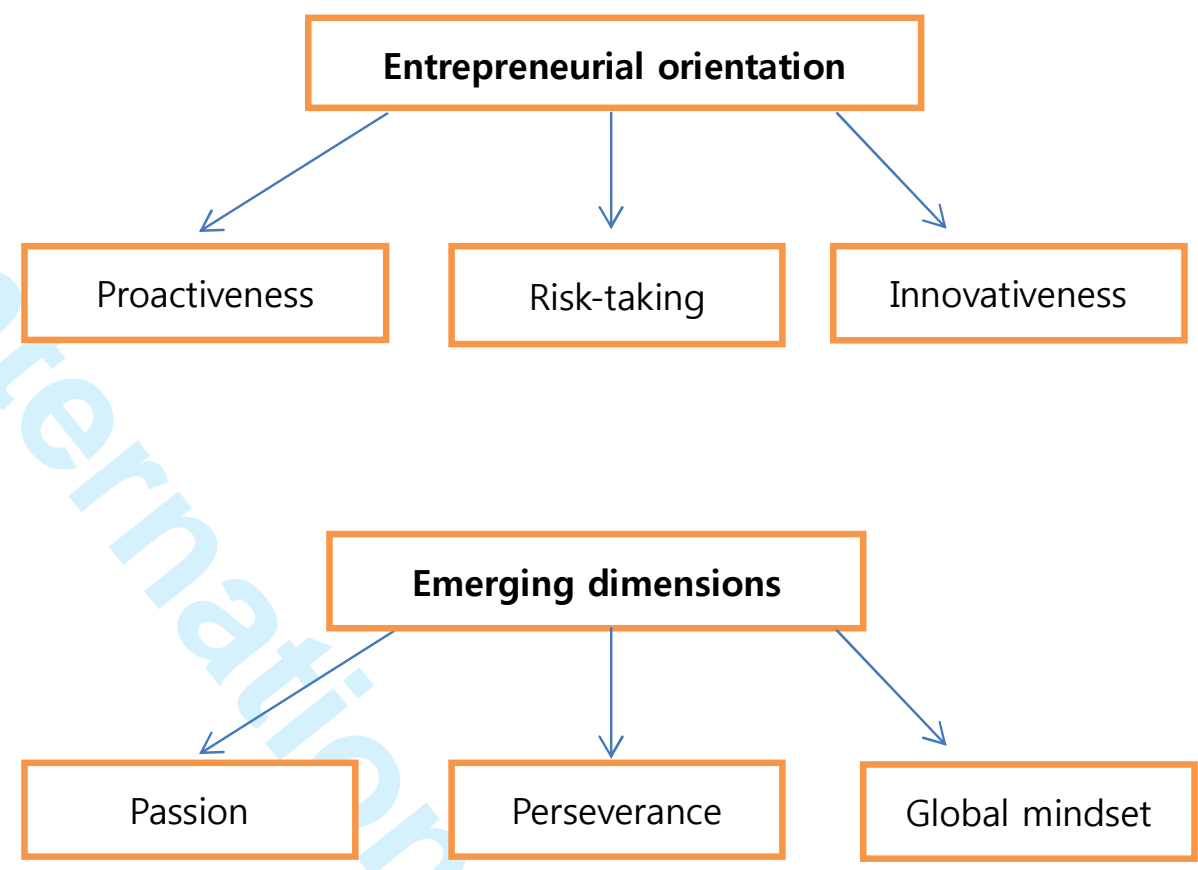

28

29

30

31

32

33

34

35

36

37

38

39

40

41

42

43

44

45

46

47

48

49

50

51

52

53

54

55

56

57

58

59 
Table 3: Dimensions of EO from interviews

\begin{tabular}{lllllll}
\hline & & & EO dimensions & & \\
\hline FOOD & Proactiveness & Risk-taking & Innovativeness & Perseverance & Passion \\
\hline ICT1 & Strongly present & Low degree & Strongly present & Strongly present & Strongly present \\
\hline ICT2 & Strongly present & Low degree & Strongly present & Strongly present & Strongly present \\
\hline EDUC & Present & Low degree & Strongly present & Strongly present & Present \\
\hline OIL & Strongly present & Low degree & Strongly present & Present & Strongly present \\
\hline WINE & Strongly present & Low degree & Strongly present & Strongly present & Strongly present \\
\hline MFG1 & Present & Low degree & Present & Present & Strongly present \\
\hline MFG2 & Strongly present & Present & Strongly present & Strongly present & Strongly present \\
\hline
\end{tabular}

